\title{
PENDAMPINGAN KONSELOR SEBAYA DALAM PENCEGAHAN ANEMIA REMAJA PUTRI
}

\author{
Riyanti $^{1}$ Legawati $^{2}$ \\ Program Studi Diploma III Kebidanan Poltekkes Kemenkes Palangka Raya \\ Provinsi Kalimantan Tengah \\ Email : riyantihelena@gmail.com
}

\begin{abstract}
Anemia is a nutritional problem in the world, especially in developing countries. The incidence of female anemia in Indonesia is still high. Young women have ten times greater risk of anemia than young men. This is because teenage girls experience menstruation every month and are in a period of growth so that requires more iron intake. Efforts made in addition to providing blood-boosting tablets also involve the participation of peers in adolescent groups to prevent anemia in adolescents further through peer counselors on prevention of anemia in young women.

Methods of community service that is with Peer Counselor Assistance On Prevention of Young Women Anemia. This activity is carried out for 3 months which is divided into 3 stages: (1) planning stage, (2) implementation stage, (3) evaluation stage.

The results obtained an increase in the counseling service process from 27 at the first meeting to 32.33 at the third meeting
\end{abstract}

Keyword : Prevention of Anemia, Peer counselors, Teenage girls

\begin{abstract}
Abstrak
Anemia merupakan masalah gizi di dunia, terutama di negara berkembang. Angka kejadian anemia remaja putri di Indonesia masih cukup tinggi. Remaja putri memiliki risiko sepuluh kali lebih besar untuk menderita anemia dibandingkan dengan remaja putra. Hal ini dikarenakan remaja putri mengalami menstruasi setiap bulannya dan sedang dalam masa pertumbuhan sehingga membutuhkan asupan zat besi yang lebih banyak. Upaya yang dilakukan selain memberikan tablet tambah darah juga melibatkan peran serta dari teman sebaya pada kelompok remaja untuk mencegah anemia pada remaja lebih lanjut melalui konselor teman sebaya tentang pencegahan anemia pada remaja putri.

Metode pengabdian kepada masyarakat yaitu dengan Pendampingan Konselor Sebaya Pada upaya Pencegahan Anemia Remaja Putri. Kegiatan ini dilaksanakan di SMA Isen Mulang Palangka Raya selama 3 bulan yang terbagi dalam 3 tahap yaitu: (1) tahap perencanaan, (2) tahap pelaksanaan, (3) tahap evaluasi.

Hasil didapatkan peningkatan proses layanan konseling dari 27 pada pertemuan pertama menjadi 32,33 pada pertemuan ketiga, sedangkan penilaian hasil layanan konseling semuanya dengan kriteria sangat baik $(41,8)$.

Simpulan: kegiatan pendampingan konselor sebaya dalam pencegahan anemia remaja putri dapat meningkatkan pengetahuan, sikap dan perilaku remaja putri dalam mencegah anemia.
\end{abstract}

\section{Kata Kunci: Konselor Sebaya, Pencegahan Anemia, Remaja Putri}

\section{Pendahuluan}

Anemia dapat terjadi di setiap kelompok umur termasuk remaja. Anemia pada remaja merupakan masalah kesehatan masyarakat yang serius karena dapat memperlambat perkembangan psikomotor dan kognitif ${ }^{1}$. Kelompok usia remaja merupakan kelompok yang cukup besar, sekitar $23 \%$ dari seluruh populasi. Sebagai generasi penerus, kelompok ini merupakan 
aset atau modal utama sumber daya manusia bagi pembangunan bangsa di masa yang akan datang. Kelompok remaja yang berkualitas memegang peranan penting didalam mencapai didalam mencapai kelangsungan serta keberhasilan tujuan pembangunan nasional.

Menurut WHO masa remaja (10 sampai 19 tahun) adalah periode rentan mengalami anemia karena pertumbuhan yang cepat dan perubahan perilaku, diet dan kebiasaan gaya hidup. Remaja (usia 10-19 tahun) beresiko tinggi kekurangan zat besi dan karena peningkatan kebutuhan zat besi, kurangnya asupan makanan yang mengandung zat besi, tingginya tingkat infeksi dan infeksi cacing serta norma sosial pernikahan dini dan kehamilan remaja (WHO, 2012).

Remaja putri memiliki risiko sepuluh kali lebih besar untuk menderita anemia dibandingkan dengan remaja putra. Hal ini dikarenakan remaja putri mengalami menstruasi setiap bulannya dan sedang dalam masa pertumbuhan sehingga membutuhkan asupan zat besi yang lebih banyak. Selain itu, ketidakseimbangan asupan zat gizi juga menjadi penyebab anemia pada remaja. Remaja putri biasanya sangat memperhatikan bentuk tubuh, sehingga banyak yang membatasi konsumsi makanan dan banyak pantangan terhadap makanan (Backstrand dkk, 2002). Remaja putri merupakan salah satu kelompok yang rawan menderita anemia.

Oleh karena itu, sasaran program penanggulangan anemia gizi telah dikembangkan yaitu mencapai remaja putri SMP, SMA, dan sederajat, serta wanita di luar sekolah sebagai upaya strategis dalam upaya memutus simpul siklus masalah gizi. Walaupun begitu, prevalensi anemia di kalangan remaja putri masih tergolong dalam kategori tinggi. Hasil penelitian dari Ayu Anggraeni (2010) menunjukkan bahwa prevalensi anemia gizi pada remaja putri di 5 wilayah Jakarta adalah 44,6 \%. Anemia adalah keadaan di mana terjadi penurunan jumlah massa eritrosit (red cell mass) yang ditunjukkan oleh penurunan kadar hemoglobin, hematokrit, dan hitung eritrosit (red cell count) (Bakta, 2006). Sintesis hemoglobin memerlukan ketersediaan besi dan protein yang cukup dalam tubuh. Protein berperan dalam pengangkutan besi ke sumsum tulang untuk membentuk molekul hemoglobin yang baru (Gallagher dkk, 2008). Anemia dapat menyebabkan lekas lelah, konsentrasi belajar menurun sehingga prestasi belajar rendah dan dapat menurunkan produktivitas kerja. Di samping itu juga menurunkan daya tahan tubuh sehingga mudah terkena infeksi (National Anemia Action Council,2009).

Data Survey Kesehatan Rumah Tangga tahun 2012 menunjukkan prevalensi anemia remaja putri di Indonesia sebesar 57,1\% meningkat dari hasil SKRT tahun 2008 sebesar 6,5\%, sedangkan data Riskesdas tahun 2013 didapatkan anemia pada usia 5-14 tahun sebesar 26,4\% dan pada kelompok usia 15-24 tahun sebesar 18,4\%. Prevalensi anemia yang tinggi dikalangan remaja jika tidak tertangani dengan baik akan berlanjut hingga dewasa dan berkontribusi besar terhadap angka kematian ibu, bayi lahir prematur, dan bayi dengan berat lahir rendah. Berbagai upaya dilakukan pemerintah untuk menanggulangi masalah anemia pada remaja saat ini seperti pemberian tablet tambah darah, tetapi upaya lain sebaiknya perlu dipertimbangkan misalnya dengan melibatkan peran serta dari teman sebaya pada kelompok remaja untuk mencegah anemia pada remaja lebih lanjut. Pada masa remaja, ketertarikan dan komitmen serta ikatan terhadap teman sebaya sangat kuat. karena remaja merasa bahwa orang dewasa tidak dapat memahami mereka. Keadaan ini sering menjadikan remaja sebagai suatu kelompok yang eksklusif karena hanya sesama merekalah dapat saling memahami. Sebagian besar lebih sering membicarakan masalah-masalah serius mereka dengan teman sebaya, dibandingkan dengan orang tua dan guru pembimbing (Suwarjo,2008).

Aisah A dkk (2008) di Semarang menyatakan bahwa intervensi edukasi kelompok sebaya mempengaruhi pengetahuan, sikap dan keterampilan wanita 
usia subur tentang pencegahan anemia. Hal ini juga didukung penelitian dari $\mathrm{N}$ Inez dkk tahun 2014 bahwa dukungan kelompok sebaya dapat meningkatkan pengetahuan, sikap dan tindakan wanita hamil pada pencegahan anemia. Dukungan kelompok sebaya membantu wanita hamil untuk mendapatkan banyak informasi dari anggota lain dan juga membantu mereka untuk menemukan jalan keluar dari masalah nya tentang pencegahan anemia. Menurut Pareek dan Hafiz (2015) Konseling dapat meningkatkan kemampuan remaja untuk memahami pentingnya pencegahan anemia dengan mengkonsumsi makanan yang kaya zat besi.

Menurut SKRRI tahun 2012, sekitar 29\% remaja perempuan memperoleh informasi tentang kesehatan reproduksi dari teman sebaya. Remaja perempuan lebih suka mencurahkan hati tentang kesehatan reproduksi dengan temannya dibandingkan dengan orang tua atau guru. Melihat kecenderungan tersebut, maka dibutuhkan seorang sumber informasi yang tepat dan benar yang mampu membantu remaja untuk sehat secara fisik maupun psikologis.

Konselor sebaya remaja putri di SMA diharapkan dapat membawa dampak keberhasilan untuk upaya pencegahan bertambahnya penderita anemia di kelompok remaja putri dan mengingat dampak yang terjadi akibat anemia sangat merugikan kualitas kerja dan mutu sumber daya manusia di masa mendatang dan remaja putri mempunyai multi peran yaitu sebagai remaja yang sekolah dan juga calon ibu. Upaya yang dapat dilakukan untuk meningkatkan kualitas remaja putri antara lain adalah dengan meningkatkan kualitas pelayanan pencegahan anemia, termasuk kualitas dalam memberikan informasi tentang anemia dan pelayanan konseling, sehubungan dengan hal tersebut perlu dilaksanakan pendampingan konselor sebaya pada upaya pencegahan anemia remaja putri.

\section{Metode Pelaksanaan}

Metode pemecahan masalah dilakukan melalui kegiatan Pendampingan Konselor
Sebaya Pada upaya Pencegahan Anemia Remaja Putri. Kegiatan ini dilaksanakan selama 3 bulan sejak bulan Juni 2017 sampai dengan Agustus 2017 yang terbagi dalam 3 tahap yaitu: (1) tahap perencanaan, (2) tahap pelaksanaan, (3) tahap evaluasi.

Tahap perencanaan dilaksanakan dimulai dari pembuatan proposal, pemilihan lokasi. Jenis kegiatan adalah Pendampingan Konselor Sebaya Pada Pada upaya Pencegahan Anemia Remaja Putri. Tahap selanjutnya adalah pelaksanaan yaitu melatih beberapa siswi dalam hal dengan kriteria siswi pengurus OSIS di SMA Isen Mulang Palangka Raya dan dilanjutkan praktik konseling pada teman sebaya. Pada tahap terakhir yaitu evaluasi pelaksanaan kegiatan, evaluasi dilakukan sebanyak 3 kali. Adapun metode pengabdian masyarakat kegiatan ini adalah pemutaran video, ceramah, tanya jawab, diskusi dan praktik konseling yang dikemas dalam bentuk pelatihan.

\section{Hasil dan Pembahasan}

Kegiatan pengabdian kepada masyarakat melalui Pendampingan Konselor Sebaya Pada Pada upaya Pencegahan Anemia Remaja Putri dilaksanakan tanggal 09, 16 dan 23 September 2017. Kegiatan pendampingan berjalan dengan lancar pada pertemuan pertama dihadiri 3 orang siswi sesuai dengan kriteria yaitu pengurus OSIS di SLTA Isen Mulang Palangka Raya, Pertemuan evaluasi kedua dihadiri oleh 6 orang remaja putri dan pada pertemuan ketiga dihadiri 12 orang remaja putri (siswi). Peserta terlihat antusias dengan materi yang diberikan. Hal ini terlihat dari awal hingga akhir kegiatan, semua peserta mengikuti dengan baik. Peserta mampu memberikan konseling pada teman sebaya dengan baik dan menggunakan media booklet yang telah disiapkan.

Berdasarkan evaluasi menggunakan instrument penilaian hasil layanan konseling bagi siswa dan penilaian proses layanan konseling maka didapatkan hasil sebagai berikut;

Tabel 1. Penilaian Proses Layanan Konseling 


\begin{tabular}{ccccc}
\hline $\begin{array}{c}\text { Pertemua } \\
\text { n Ke }\end{array}$ & $\begin{array}{c}\text { Rata } \\
\text {-rata } \\
\text { nilai }\end{array}$ & $\begin{array}{c}\text { Kriteri } \\
\text { a hasil }\end{array}$ & $\begin{array}{c}\text { Keteranga } \\
\mathbf{n}\end{array}$ \\
\hline 1 & 27 & Baik & $\begin{array}{l}3 \\
\text { orang } \\
\text { konselor }\end{array}$ \\
\hline 2 & 31 & Baik & $\begin{array}{l}6 \quad \text { orang } \\
\text { konselor }\end{array}$ \\
\hline 3 & 32,33 & Baik & $\begin{array}{l}12 \text { orang } \\
\text { konselor }\end{array}$ \\
\hline
\end{tabular}

Berdasarkan penilaian proses layanan konseling yang dilaksanakan oleh konselor, rata-rata nilai dengan kriteria baik, terkait materi pencegahan anemia pada remaja putri, sedangkan penilaian hasil layanan konseling yang didapatkan dari siswi yang dilayani konseling adalah sebagai berikut:

Tabel 2. Penilaian hasil layanan konseling bagi siswa

\begin{tabular}{cccc}
\hline $\begin{array}{c}\text { Pertemua } \\
\text { n Ke }\end{array}$ & $\begin{array}{c}\text { Rata } \\
\text {-rata } \\
\text { nilai }\end{array}$ & $\begin{array}{c}\text { Kriteri } \\
\text { a hasil }\end{array}$ & $\begin{array}{c}\text { Keteranga } \\
\mathbf{n}\end{array}$ \\
\hline 1 & 42,7 & $\begin{array}{c}\text { Sangat } \\
\text { Baik }\end{array}$ & $\begin{array}{c}3 \text { orang } \\
\text { siswi }\end{array}$ \\
\hline 2 & 40,25 & $\begin{array}{c}\text { Sangat } \\
\text { Baik }\end{array}$ & $\begin{array}{c}\text { 6 orang } \\
\text { siswi }\end{array}$ \\
\hline 3 & 41,8 & $\begin{array}{c}\text { Sangat } \\
\text { Baik }\end{array}$ & $\begin{array}{c}12 \text { orang } \\
\text { siswi }\end{array}$ \\
\hline
\end{tabular}

Tabel 2 memperlihatkan kriteria hasil penilaian siswa terhadap layanan menyatakan sangat baik. Materi mengenai anemia sangat penting bagi remaja putri, untuk mencegah terjadinya anemia pada remaja putri, jika anemia terjadi berdampak pada penurunan kualitas remaja sebagai generasi penerus baik kualitas belajar maupun persiapan sebagai calon ibu. Kegiatan diawali dengan perkenalan antara narasumber dan peserta, dilanjutkan dengan penyampaian materi, bermain peran dan praktik konseling serta tanya jawab. Pada pertemuan evaluasi dilakukan praktik konseling teman sebaya Satuan Acara kegiatan, materi, media dan daftar hadir peserta terlampir.

Hasil pengabdian kepada masyarakat tentang edukasi teman sebaya mengenai pencegahan anemia pada remaja putri menunjukkan perubahan yang baik, dan adanya peningkatan pemahaman. Masa remaja adalah masa transisi antara masa anak ke masa dewasa, terjadinya perubahan yang pesat secara biologis, intelektual, dan psikososial. Saat ini, $20 \%$ dari tinggi orang dewasa dan $50 \%$ dari berat badan orang dewasa tercapai. Karena pertumbuhan yang cepat ini, remaja sangat rentan terhadap anemia. Nutrisi yang tepat, termasuk asupan zat besi yang cukup, merupakan bagian penting dari pertumbuhan dan perkembangan remaja. Selama masa remaja, remaja akan memperoleh pengetahuan dan keterampilan yang akan membantu mereka untuk menjadi mandiri dan sukses, tapi anemia defisiensi besi dapat mempengaruhi pembelajaran, pertumbuhan dan perkembangan mereka ( $R$ Minakshi dkk, 2012)

Anemia adalah suatu kondisi dimana jumlah sel darah merah atau jumlah hemoglobin rendah. Sel darah merah mengandung protein hemoglobin yang akan membawa oksigen dari paru-paru dan mengirimkannya ke seluruh bagian tubuh. Ketika jumlah sel darah merah berkurang atau jumlah hemoglobin juga rendah, darah tidak dapat membawa pasokan yang cukup oksigen. Jika pasokan oksigen dalam jaringan berkurang maka akan menghasilkan gejala anemia. Bahkan ada banyak gangguan darah; kekurangan zat besi anemia adalah gangguan gizi yang paling banyak di dunia saat ini. Besi merupakan mineral yang diperlukan untuk fungsi tubuh dan baik kesehatan. Setiap sel darah merah dalam tubuh mengandung zat besi dalam hemoglobin-nya, pigmen yang membawa oksigen ke jaringan dari paru-paru. Tapi kekurangan zat besi dalam darah dapat menyebabkan anemia, yang banyak terjadi pada anak-anak dan remaja (R. Minakshi, 2012).

Anemia dapat disebabkan oleh beberapa faktor. Penyebab utama anemia yang paling umum diketahui adalah : (1) kurangnya kandungan zat besi dalam makanan, (2) penyerapan zat besi dari makanan yang sangat rendah, (3) adanya zatzat yang menghambat penyerapan zat besi, 
dan (4) adanya parasit di dalam tubuh seperti cacing tambang atau cacing pita, atau kehilangan banyak darah akibat kecelakaan atau operasi (Biesalski dan Erhardt, 2007). Defisiensi zat besi dari makanan biasanya menjadi faktor utama. Jika zat besi yang dikonsumsi terlalu sedikit atau bioavailabilitasnya rendah atau makanan berinteraksi dengan membatasi absorpsi yang dibutuhkan tubuh untuk memenuhi kebutuhan zat besi, cadangan zat besi dalam tubuh akan digunakan dan hal tersebut dalam menimbulkan defisiensi zat besi (Gleason \& Scrimshaw, 2007).

Kebutuhan zat besi sangat banyak selama masa remaja karena pubertas mengalami pertumbuhan cepat dengan peningkatan pesat dalam massa tubuh tanpa lemak, volume darah dan massa sel darah merah, sehingga meningkatkan kebutuhan zat besi untuk mioglobin dalam otot dan hemoglobin dalam darah. Kebutuhan penyerapan zat besi akan terus meningkat pada anak laki-laki dan perempuan selama masa remaja antara usia 14-15 tahun untuk anak perempuan dan satu sampai dua tahun kemudian untuk anak lakilaki (WHO,2012). Remaja memiliki pertumbuhan yang cepat (growth spurt) dan merupakan masa pertumbuhan yang intens setelah masa bayi serta satu-satunya periode dalam hidup individu dimana terjadi peningkatan velositas pertumbuhan. Selama masa remaja, seseorang dapat mencapai 15 persen dari tinggi badan dan 50 persen dari berat badan saat dewasa. Pertumbuhan yang cepat ini sejalan dengan peningkatan kebutuhan zat gizi, yang secara signifikan dipengaruhi oleh infeksi dan pengeluaran energi (UNS-SCN 2006).

Perempuan cenderung mempunyai simpanan zat besi yang lebih rendah dibandingkan pria, membuat perempuan lebih rentan mengalami defisiensi zat besi saat asupan zat besi kurang atau kebutuhan meningkat. Jika zat besi yang dikonsumsi terlalu sedikit atau bioavailabilitasnya rendah atau makanan berinteraksi dengan membatasi absorpsi yang dibutuhkan tubuh untuk memenuhi kebutuhan zat besi, cadangan zat besi dalam tubuh akan digunakan dan hal tersebut dalam menimbulkan defisiensi zat besi. Status zat besi tiap individu bermacammacam mulai dari excess zat besi sampai anemia defisiensi zat besi. Walaupun kebutuhan zat besi bervariasi pada tiap grup yang tergantung pada faktor-faktor seperti pertumbuhan (bayi, remaja, kehamilan) dan perbedaan kehilangan normal zat besi (menstruasi dan kelahiran), terjadi proses yang diatur tubuh dalam meningkatkan absorpsi zat besi sejalan dengan penggunaan zat besi dan menurunkan absorpsi zat besi yang disimpan di dalam tubuh sejalan dengan adanya asupan makanan (Gleason \& Scrimshaw 2007).

Masa remaja adalah waktu yang tepat untuk intervensi dalam mengatasi anemia. Tidak hanya untuk kebutuhan (pertumbuhan, persiapan untuk kehamilan), tapi dapat dicapai dengan mudah jika sekolah ikut hadir atau partisipasi dalam kegiatan kelompok. Remaja terbuka untuk informasi baru dan praktek-praktek baru karena mereka sering berjuang untuk keunggulan fisik atau akademik. Fokus strategis pada pencegahan anemia pada kalangan remaja lebih penting dari sudut pandang produktivitas dari peningkatan kapasitas fisik; keuntungan produktivitas dari peningkatan kemampuan kognitif; serta (untuk remaja perempuan) memperbaiki hasil kehamilan dan bermanfaat antargenerasi. (WHO,2012) salah satu upaya yang dilakukan melalui adanya konselor sebaya.

Konselor sebaya ini sangat potensial karena adanya kecenderungan pada remaja untuk memilih teman sebaya sebagai tempat berdiskusi dan rujukan informasi (Kemenkes RI,2010). Selain Kementerian Kesehatan, pelayanan kesehatan remaja terkait kesehatan reproduksi juga diberikan oleh BKKBN dengan program PIK-KRR. Salah satu program dari PKPR dan PIK-KRR adalah mengoptimalkan peran teman sebaya sebagai role model sekaligus memberikan konseling bagi remaja terkait dengan kesehatan reproduksi remaja. Konseling yang diberikan oleh teman sebaya diharapkan dapat lebih dipercaya, sehingga remaja lebih terbuka untuk menyampaikan setiap masalah 
yang dihadapi (Simba DO dan Kakoko, 2009) Teman sebaya memiliki peran penting dalam kehidupan sosial dan perkembangan remaja Informasi mengenai kesehatan reproduksi yang diperoleh melalui teman sebaya (peer) dapat mendorong remaja memiliki pengetahuan yang lebih baik. Melalui teman sebaya (peer) dapat mendorong remaja memiliki pengetahuan yang lebih baik.

\section{Simpulan dan Saran}

Upaya meningkatkan pengetahuan, sikap dan keterampilan remaja putri tentang pencegahan anemia melalui kegiatan pendampingan konselor teman sebaya sangat penting. Kegiatan ini dilaksanakan sebagai salah satu upaya menurunkan berbagai permasalahan kesehatan akibat anemia pada remaja dan juga calon ibu. Diperlukan kerjasama lintas sektoral dan program untuk melaksanakan pelayanan kesehatan reproduksi yang peduli pada remaja dalam rangka mempersiapkan generasi penerus yang berkualitas.

\section{Daftar Pustaka}

Aulakh R. Adolescent Anemia: Risk Factors. Int J Pediatr Res.2016;3(7):478479.doi:10.17511/ijpr.2016.7.15

Available online at:
www.pediatricreview.in

Anggraeni A. 2010. Faktor-Faktor Yang Berhubungan Dengan Status Anemia Gizi Besi Pada Siswi SMU Di Wilayah DKI Jakarta. Jakarta: BKPI-LIPI.

Backstrand JR, LH Allen, AK Black, M Demata, GH Pelto. 2002. Diet And Iron Status Of Nonpregnant Women In Rural Central Mexico. The Journal Of Nutrition 76:156-64

Bakta IM, Pendekatan Terhadap Pasien Anemia. In : Sudoyo AW, Bambang Setiyohadi, Idrus Alwi, Marcellus Simadibrata K, Siti Setiati, Editors. Buku Ajar Ilmu Penyakit Dalam. Edisi IV, Jilid II. Jakarta Pusat: Pusat Penerbitan Ilmu Penyakit Dalam FK UI; 2006.P.622-623.
Badan Pusat Statistik (BPS), Badan Koordinasi Keluarga Berencana Nasional (BKKBN), Kementerian Kesehatan (Kemenkes), ICF International. Survei Demografi Kesehatan Indonesia 2012: Kesehatan Reproduksi Remaja. Jakarta: BPS, BKKBN, Kemenkes Dan ICF Internasional; 2013.

Briawan D. 2008. Efikasi suplementasi besimultivitamin terhadap perbaikan status besi remaja wanita [disertasi]. Bogor : Sekolah Pasca Sarjana, Institut Pertanian Bogor

Chaudhary S M And Vasant R D.2008 A Study Of Anemia Among Adolescent Females In The Urban Area Of Nagpur; Indian J Community Med; V.33(4); 2008. P.243-245.

Gallagher ML. 2008. The Nutrients And Their Metabolism. In : Mahan LK, Escott-Stump S. Krause's Food, Nutrition, And Diet Therapy. 12th Edition. Philadelphia: Saunders;.

Kementerian kesehatan RI. 2011. Modul Pelatihan Pelayanan Kesehatan Peduli Remaja. Bagi Konselor. Jakarta

Kementerian Kesehatan RI. 2011. Modul Pelatihan Pelayanan Kesehatan Peduli Remaja. Bagi Tenaga Kesehatan. Jakarta Minakshi R,. Varghese R,Ravindra H N.2015. A Study to Assess the Effectiveness of Structured Teaching Program on Knowledge Regarding Iron Deficiency Anemia and Its Prevention Among Early Adolescent Girls in Selected Schools of Bhavnagar District; Paripex - Indian Journal Of Research Vol 4(5).

National Anemia Action Council. Anemia In Adolescents : The Teen Scene. 2009 January 14 Available From: Http://Www.Anemia.Org.

Pareek P, Hafiz A.2015. A Study on Anemia Related Knowledge Among Adolescent Girls; International Journal of Nutrition and Food Sciences 2015; 4(3): 273-276 doi: 10.11648/j.ijnfs.20150403.14 
Permaesih D dan Herman S. 2005. FaktorFaktor Yang Mempengaruhi Anemia Pada Remaja Bul. Penel. Kesehatan, Vol. 33, No. 4, ,2005: 162-171

Suwarjo.2008.Pedoman Konseling Teman Sebaya untuk Pengembangan Resiliensi.FKIP;UNY;Yogyakarta

Thompson B. 2007. Food-based approaches for combating iron deficiency. Didalam Nutritional Anemia, Edited by Klaus Kraemer \& Michael B. Zimmermann. Switzerland : Sight and Life Press

WHO, 2012. Prevention Of Deficiency Anaemia In Adolescents Role Of Weekly Iron And Folic Acid Supplementation. 